\title{
Acid Lipase from Candida viswanathii: Production, Biochemical Properties, and Potential Application
}

\author{
Alex Fernando de Almeida, ${ }^{1}$ Sâmia Maria Tauk-Tornisielo, ${ }^{1}$ and Eleonora Cano Carmona ${ }^{2}$ \\ ${ }^{1}$ Environmental Studies Center, Universidade Estadual Paulista, CEA/UNESP, Avenida 24-A, 1515 Bela Vista, \\ 13506-900 Rio Claro, SP, Brazil \\ ${ }^{2}$ Biochemistry and Microbiology Department, Bioscience Institute, Universidade Estadual Paulista, IB/UNESP, \\ Avenida 24-A, 1515 Bela Vista, 13506-900 Rio Claro, SP, Brazil \\ Correspondence should be addressed to Eleonora Cano Carmona; ecarmona@rc.unesp.br
}

Received 25 July 2013; Accepted 8 October 2013

Academic Editor: S. L. Mowbray

Copyright (c) 2013 Alex Fernando de Almeida et al. This is an open access article distributed under the Creative Commons Attribution License, which permits unrestricted use, distribution, and reproduction in any medium, provided the original work is properly cited.

\begin{abstract}
Influences of environmental variables and emulsifiers on lipase production of a Candida viswanathii strain were investigated. The highest lipase activity $(101.1 \mathrm{U})$ was observed at $210 \mathrm{rpm}, \mathrm{pH} 6.0$, and $27.5^{\circ} \mathrm{C}$. Other fermentation parameters analyzed showed considerable rates of biomass yield $\left(Y_{L / S}=1.381 \mathrm{~g} / \mathrm{g}\right)$, lipase yield $\left(Y_{L / S}=6.892 \mathrm{U} / \mathrm{g}\right)$, and biomass productivity $\left(P_{X}=0.282 \mathrm{~g} / \mathrm{h}\right)$. Addition of soybean lecithin increased lipase production in 1.45-fold, presenting lipase yield $\left(Y_{L / S}\right)$ of $10.061 \mathrm{U} / \mathrm{g}$. Crude lipase presented optimal activity at acid $\mathrm{pH}$ of 3.5, suggesting a new lipolytic enzyme for this genus and yeast in general. In addition, crude lipase presented high stability in acid conditions and temperature between 40 and $45^{\circ} \mathrm{C}$, after $24 \mathrm{~h}$ of incubation in these temperatures. Lipase remained active in the presence of organic solvents maintaining above $80 \%$ activity in DMSO, methanol, acetonitrile, ethanol, acetone, 1-propanol, isopropanol, and 2-propanol. Effectiveness for the hydrolysis of a wide range of natural triglycerides suggests that this new acid lipase has high potential application in the oleochemical and food industries for hydrolysis and/or modification of triacylglycerols to improve the nutritional properties.
\end{abstract}

\section{Introduction}

Lipases (triacylglycerol acyl hydrolase, EC 3.1.1.3) are responsible for the hydrolysis of triglyceride ester bonds into diglycerides, monoglycerides, fatty acids, and glycerol using a complex phenomenon of interfacial activation. Lipases present a number of unique characteristics, including substrate specificity, stereospecificity, and the ability of the resolution of racemic mixtures and synthesis of esters bonds in nonaqueous media [1]. The potential for industrial applications of lipases comprises the industry of additives (modification of aromas), food (monoacylglycerols and diacylglycerols), fine chemistry (ester synthesis), detergents (hydrolysis of fats), wastewater treatment (decomposition and removal of oleaginous substances), leather (fat removal from animal skin), pharmaceutical, and medical area (medicines, digestive aid, and enzymes for diagnosis) [2-5].
Lipases are ubiquitous and indispensable for triacylglycerols bioconversion in nature. They occur in plants, animals, and microorganisms [6], but the most lipases commercially produced are isolated from fungi, yeast, and bacteria $[5,7,8]$. Microbial enzymes are often more utilized than enzymes from plants or animals because of the diversity of catalytic activities, the high yields, ease of genetic manipulation, regular supply due to absence of seasonal variations, and rapid growth of microorganisms on inexpensive media [9]. Microbial lipases are biocatalysts that have interesting characteristics such as action under mild conditions, stability in organic solvents, high substrate specificity, and regio- and enantioselectivity $[3,10]$.

The use of the submerged culture is advantageous because of the facility of sterilization and process control in these systems. Depending on the strain and the culture conditions, the enzyme can be constitutive or inducible, showing different 
production. Submerged fermentation processes for the lipolytic enzymes production usually employ renewable lowcost hydrophobic substrates such as vegetable oil, poultry fat, tallow, waste fats, soap stocks, rapeseed oil, and grease containing waste water [11]. The use of these carbon sources for synthesis of high-added value products, as single-cell protein, microbial lipids, organic acids, biosurfactants, and lipases, is considered of great economic and ecological significance [12].

Environmental factors such as oxygen, agitation, temperature, and $\mathrm{pH}$ are important parameters that affect extracellular lipase production and must be considered in submerged process. Temperature and $\mathrm{pH}$ can be determined in shake flasks fermentations $[13,14]$, but agitation and oxygenation of the culture should be specifically studied in the course of the scale-up process [15-17]. Another important point considered in lipases studies is the biochemical characterization of the crude enzymes. This is frequently used to know the catalytic properties of enzymes, since in general no large quantities of pure enzymes can be obtained after purification without these data [18]. Moreover, in some lipase industrial applications this is not necessary because homogenous preparations are not required [19].

In a previous study, a strain of Candida viswanathii was capable to produce lipase and biomass efficiently when cultured in a large diversity of natural triacylglycerols [20]. In this work, the influence of environmental factors such as agitation, $\mathrm{pH}$, and temperature, and surfactants supplementation were investigated to improve the lipase production by this yeast. In addition, the lipase produced under the best culture conditions was biochemically characterized and the potential application for triacylglycerols hydrolysis was evaluated.

\section{Materials and Methods}

2.1. Microorganisms and Growth Conditions. C. viswanathii strain is available in the Culture Collection of the Environmental Studies Center, CEA/UNESP, Brazil. C. viswanathii was cultivated on malt extract agar (MEA) for 3 days, at $28^{\circ} \mathrm{C}$, for inoculum preparation. Liquid medium was prepared using Vogel's medium, with $1.5 \%(\mathrm{w} / \mathrm{v})$ olive oil and $0.2 \%(\mathrm{w} / \mathrm{v})$ yeast extract as single carbon and nitrogen sources, respectively, according to the conditions established previously [20]. Erlenmeyer flasks (125 mL) containing $25 \mathrm{~mL}$ of medium were inoculated with $1.0 \mathrm{~mL}$ of cells suspension $\left(1.0 \times 10^{7}\right.$ cells $\left./ \mathrm{mL}\right)$ and incubated at different conditions as indicated subsequently. All cultures were developed in triplicate and the results were assayed for biomass, maximum lipase activity, biomass yield on substrate, lipase yield on substrate, biomass productivity, and specific rate of lipase production.

Biomasses were separated from the fermentation broth by filtration. Cell-free broth was used for lipase activity determination. Biomasses were dried at $105^{\circ} \mathrm{C}$ until constant mass.

2.2. Effect of Agitation on Lipase Production. The culture was carried out in an orbital shake at $150 \mathrm{rpm}, 180 \mathrm{rpm}$, and
$210 \mathrm{rpm}$. Initial $\mathrm{pH}$ was adjusted to 6.0 and the incubation temperature was $27.5^{\circ} \mathrm{C}$. Fermentation parameters were monitored in different intervals for $96 \mathrm{~h}$.

2.3. Effect of Initial $\mathrm{pH}$ and Temperature on Lipase Production. The effect of initial $\mathrm{pH}$ on lipase production was analyzed from 3.0 to 10.0. The initial medium $\mathrm{pH}$ was adjusted by the addition of $\mathrm{NaOH} 1 \mathrm{M}$ or $\mathrm{HCl} 1 \mathrm{M}$. Cultures were carried out for $72 \mathrm{~h}, 210 \mathrm{rpm}$ orbital shake, at $27.5^{\circ} \mathrm{C}$.

The temperature influence on lipase production was varied from 20 to $40^{\circ} \mathrm{C}$, with intervals of $2.5^{\circ} \mathrm{C}$. Cultures were carried out for $72 \mathrm{~h}, 210 \mathrm{rpm}$ orbital shake, and $\mathrm{pH}$ 6.0.

2.4. Effects of Emulsifiers and Surfactants on Lipase Production. Different surfactants (Tween 20, Tween 80, and Triton X-100) and emulsifiers (gum Arabic, soybean lecithin, and sodium deoxycholate) on lipase production were added to the medium at $0.1 \%(\mathrm{w} / \mathrm{v})$. Cultures were carried out for $72 \mathrm{~h}$, $210 \mathrm{rpm}$ orbital shake, and $\mathrm{pH} 6.0$ at $27.5^{\circ} \mathrm{C}$.

\section{Analytical Methods}

3.1. Lipase Activity Assay. Lipase activity was assayed with $\rho$ nitrophenyl-palmitate ( $\rho$ NPP) as substrate [21]. $\rho$ NPP was first dissolved in $0.5 \mathrm{~mL}$ of dimethyl sulfoxide and then diluted to $50 \mathrm{mM}$ with $50 \mathrm{mM}$ sodium phosphate buffer $\mathrm{pH}$ 7.0 containing $0.5 \%$ Triton X-100. The hydrolysis of $\rho \mathrm{NPP}$ was determined discontinuously at $37^{\circ} \mathrm{C}$ by releasing $\rho$ nitrophenol $(\rho \mathrm{NP})$. After $5 \mathrm{~min}$ of preincubation of $0.9 \mathrm{~mL}$ of this substrate solution in water bath, the reaction was started by addition of $0.1 \mathrm{~mL}$ of appropriately diluted sample. The reaction was stopped at different intervals ( 1 and $2 \mathrm{~min}$ ) by heat shock $\left(90^{\circ} \mathrm{C}, 1 \mathrm{~min}\right)$, followed by addition of $1 \mathrm{~mL}$ of saturated sodium tetraborate solution. The absorbance was measured at $405 \mathrm{~nm}$ and the activity was determined according to the standard curve carried out with $\rho$-nitrophenol ( $\rho \mathrm{NP}$ molar extinction coefficient: $\left.1.8 \times 10^{4} \mathrm{M}^{-1} \mathrm{~cm}^{-1}\right)$. Controls were prepared without enzyme. One unit of enzyme activity was defined as the amount of enzyme that releases $1 \mu \mathrm{mol}$ of $\rho \mathrm{NP}$ per $\mathrm{mL}$ per min.

3.2. Protein Analysis. The protein was determined by the Lowry method [22], using bovine serum albumin as standard.

\section{Enzyme Characterization}

4.1. Optimum $p H$ and $p H$ Lipase Stability. Enzyme activity was measured at $37^{\circ} \mathrm{C}$ in different $\mathrm{pH}$ values using glycine$\mathrm{HCl} 0.05 \mathrm{M}$ buffer from 2.0 to 3.0 and Mcllvaine buffer from 3.0 to 8.0. Enzyme stability was carried out with the same buffers, except from 8.6 to 10.0 when glycine- $\mathrm{NaOH}$ was used. Enzyme preparation was diluted in each buffer $(1: 2, \mathrm{v} / \mathrm{v})$ and incubated for $24 \mathrm{~h}$ at $10^{\circ} \mathrm{C}$.

4.2. Optimum Temperature and Lipase Thermal Stability. The optimum temperature was determined by incubation of the reaction mixture from 25 to $60^{\circ} \mathrm{C}$, in the McIlvaine buffer $\mathrm{pH}$ 4.0. For thermal stability, the enzyme was incubated for 
TABLE 1: Fermentation parameters of the C. viswanathii cultures performed for $72 \mathrm{~h}$.

\begin{tabular}{lcccccc}
\hline Speed rotation $(\mathrm{rpm})$ & Biomass $(\mathrm{g} / \mathrm{L})$ & Lipase $(\mathrm{U})$ & $Y_{X / S}(\mathrm{~g} / \mathrm{g})$ & $P_{X}(\mathrm{~g} / \mathrm{h})$ & $Y_{L / S}(\mathrm{U} / \mathrm{g})$ & $q_{L}(\mathrm{U} / \mathrm{g} \cdot \mathrm{h})$ \\
\hline 150 & 12.5 & 46.6 & 0.834 & 0.173 & 3.108 \\
180 & 17.4 & 80.2 & 1.164 & 0.242 & 5.350 & 0.051 \\
210 & 21.8 & 99.4 & 1.456 & 0.303 & 6.638 \\
\hline
\end{tabular}

$Y_{X / S}$ : biomass yield on substrate consumed; $P_{X}$ : biomass productivity; $Y_{L / S}$ : lipase yield on substrate consumed; $q_{L}$ : specific rate of lipase production.

different periods of time at $40,45,50$ and $60^{\circ} \mathrm{C}$ in McIlvaine buffer $\mathrm{pH} 4.0$ and the residual activity was determined in McIlvaine buffer $\mathrm{pH} 3.5$ at $40^{\circ} \mathrm{C}$.

4.3. Effect of Solvents on Lipase Activity. Methanol, ethanol, acetone, isopropanol, acetonitrile, 1-propanol, 2-propanol, and dimethylsulfoxide (DMSO) were added at $1 \%(\mathrm{v} / \mathrm{v})$ and $10 \%(\mathrm{v} / \mathrm{v})$ to the reaction medium. The relative activities were expressed as a percentage of the control.

4.4. Effect of Substances on Lipase Stability. Crude enzyme was incubated at $40^{\circ} \mathrm{C}$ for $1 \mathrm{~h}$ in the presence of substances $\mathrm{ZnSO}_{4}, \mathrm{MgSO}_{4}, \mathrm{NaCl}, \mathrm{BaCl}_{2}, \mathrm{CoCl}_{2}, \mathrm{NH}_{4} \mathrm{Cl}, \mathrm{Pb}\left(\mathrm{CH}_{3}\right.$ $\mathrm{COO})_{2}, \mathrm{CaCl}_{2}$, and EDTA at final concentration of $10 \mathrm{mM}$ and $20 \mathrm{mM}$.

4.5. Hydrolysis of Triacylglycerols. Hydrolysis of pure (tributyrin, triolein) or natural oils and fats (canola, castor, lard, linseed, maize, palm, poultry, olive, soybean, and sunflower) was developed at $40^{\circ} \mathrm{C}$ by following the titration of fatty acids released. The oils $(10 \%, \mathrm{w} / \mathrm{v})$ were emulsified in McIlvaine buffer $\mathrm{pH} 4.0$, containing $5 \%$ (w/v) Triton $\mathrm{X}-100$. The reaction was started by adding $1 \mathrm{~mL}$ of sample to $5 \mathrm{~mL}$ of this emulsion and then maintained for $30 \mathrm{~min}$ at $300 \mathrm{rpm}$ orbital agitation. The reaction was interrupted by adding $16 \mathrm{~mL}$ of an acetone : ethanol solution $(1: 1, \mathrm{v} / \mathrm{v})$ to the mixture. The fatty acids released were titrated to $\mathrm{pH} 11$ with a $0.05 \mathrm{M} \mathrm{NaOH}$ solution. One unit of enzyme activity was defined as the amount of enzyme that releases $1 \mu \mathrm{mol}$ of fatty acid per $\mathrm{mL}$ per min. The results were expressed as percentage of triolein hydrolyzed.

\section{Results and Discussion}

5.1. Effect of Agitation Speed on Lipase Production. Preliminary studies demonstrated very low growth rate and no lipase production until $72 \mathrm{~h}$ ( 3 days) of culture in stationary cultures. The subsequent experiments evaluated the agitation effect on the $C$. viswanathii growth and lipase production, and specific activity was determined. Three agitation speeds were assayed, and lipase production was found to be growthassociated with maximum after $72 \mathrm{~h}$ cultivation (Figures 1(a) and 1(c)). The peaks of lipase production and biomass were verified at $210 \mathrm{rpm}$ with values of $99.4 \mathrm{U}$ and $21.8 \mathrm{~g} / \mathrm{L}$, respectively. For cultures grown at $150 \mathrm{rpm}$ and $180 \mathrm{rpm}$, the lipase production corresponded to $46.50 \mathrm{U}$ and $80.00 \mathrm{U}$ and the cell growth to $12.1 \mathrm{~g} / \mathrm{L}$ and $17.4 \mathrm{~g} / \mathrm{L}$, respectively. The highest specific activity was also observed at $210 \mathrm{rpm}$ but after $84 \mathrm{~h}$ of cultivation (Figure 1(b)). The decrease in the extracellular lipase activity observed after $72 \mathrm{~h}$ cultivation can be attributed to the hydrolytic action of proteases [23], to the decrease in cell growth, or to adsorption of the enzyme produced at the aqueous-organic interface [24].

Other fermentation parameters analyzed in cultures performed at $210 \mathrm{rpm}$ for $72 \mathrm{~h}$ showed biomass yield $\left(Y_{X / S}\right)$ $1.456 \mathrm{~g} / \mathrm{g}$, lipase yield $\left(Y_{L / S}\right) 6.638 \mathrm{U} / \mathrm{g}$, biomass productivity $\left(P_{X}\right) 0.303 \mathrm{~g} / \mathrm{h}$, and specific rate of lipase production $\left(q_{L}\right)$ $0.062 \mathrm{U}$ of lipase/g of biomass.h (Table 1$)$. The biomass yield obtained was higher than those found in the literature, which present values considered satisfactory for single-cell protein fermentation from fatty acids, around $0.5-0.7 \mathrm{~g} / \mathrm{g}[12,25,26]$.

The results obtained in shake flasks are similar to those obtained using agitation speeds in bioreactors [17, 24, 27]. Brozzoli et al. [28] showed that lipase production by Candida cylindracea NRRL Y-17506 in olive mill wastewater was significantly affected by stirring speed using aeration of $1.0 \mathrm{vvm}$. Elibol and Ozer [15] reported that the variation in agitation speed for the Rhizopus arrhizus cultures resulted in a change in oxygen transfer rate, which in turn affected the rate and extent of cell growth and lipase production in shake flasks. However, in this study, the agitation speeds did not reduce period for production and increase lipase yield. According to Takaç et al. [24] cultures performed in batch bioreactor show considerable advantages over shake flasks cultivation in terms of lipase production and yield. Gulati et al. [29] reduced the time period for lipase production by Aspergillus terreus from $96 \mathrm{~h}$ in shake flask to $54 \mathrm{~h}$ in a bioreactor with control of dissolved oxygen and agitation. Nevertheless, shake flask culture is an important step for cell growth and lipase production comprehension and can play an important role in the scale-up process.

5.2. Effect of $p H$ and Temperature on Lipase Production. The initial $\mathrm{pH}$ of the fermentation medium is an important physical parameter that affects microbial growth and enzymes synthesis by Candida spp. strains [28, 30]. Cultivation in different initial $\mathrm{pH}$ values was used to evaluate the lipase production by $C$. viswanathii (Table 2 ). Changes in the $\mathrm{pH}$ were observed during growth in shake flasks due to the consumption of the medium nutrients or products formation. The lipase production increased with increasing $\mathrm{pH}$ up to 6.0 , in which the lipase production was higher (100.0 U). For cultures in neutral and alkaline conditions, the lipase production decreased, whereas C. viswanathii biomass levels remained almost constant (around $15 \mathrm{~g} / \mathrm{L}$ ). An optimal initial $\mathrm{pH}$ for lipase production by the yeast Pichia lynferdii was found at 7.0 [31] and for the bacteria Bacillus pumilus was 9.0 [32]. 


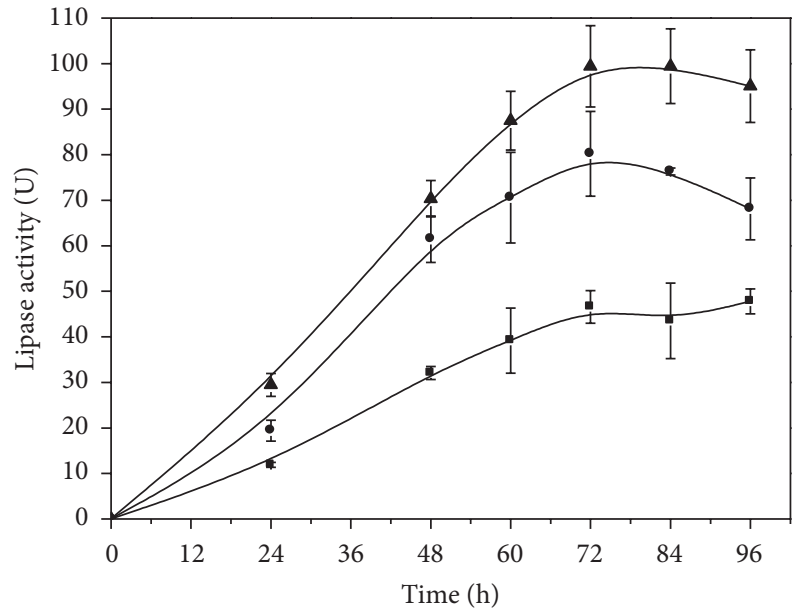

(a)

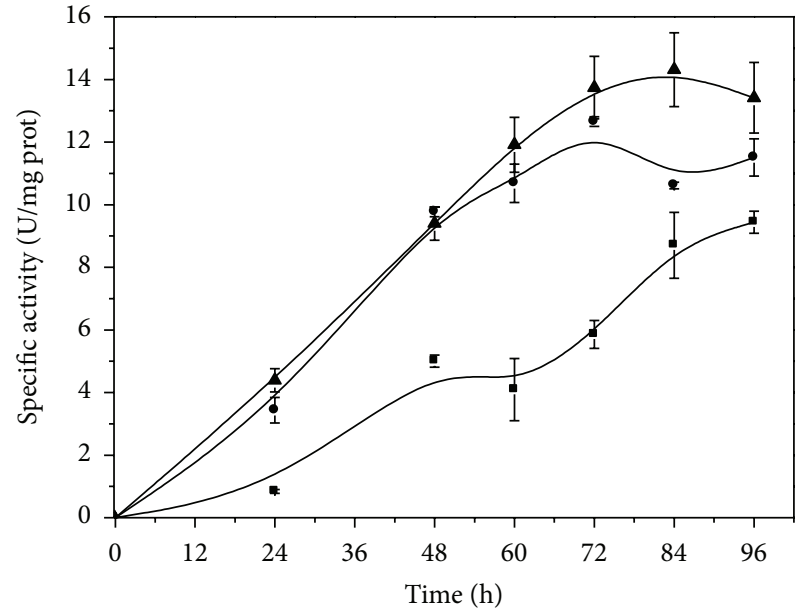

(b)

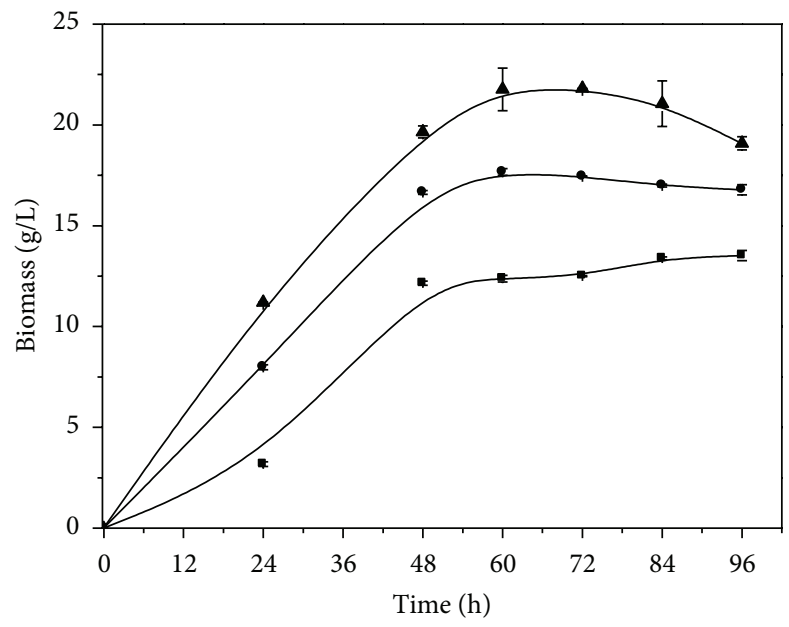

(c)

FIGURE 1: Effect of the agitation speeds in orbital shake on lipase production (a), specific activity (b), and Candida viswanathii growth (c). Culture conditions: liquid cultures were carried out in Vogel's medium with $1.5 \%$ (w/v) olive oil and $0.2 \%(w / v)$ yeast extract, at pH 6.0 and

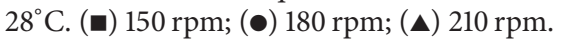

TABLE 2: Effect of culture $\mathrm{pH}$ on growth and lipase production by C. viswanathii.

\begin{tabular}{|c|c|c|c|c|c|c|c|c|}
\hline Initial $\mathrm{pH}$ & Final pH & Biomass (g/L) & $\begin{array}{c}\text { Specific activity } \\
\text { (U/mg prot) }\end{array}$ & $\begin{array}{c}\text { Lipase activity } \\
\text { (U) }\end{array}$ & $Y_{X / S}(\mathrm{~g} / \mathrm{g})$ & $P_{X}(\mathrm{~g} / \mathrm{h})$ & $Y_{L / S}(\mathrm{U} / \mathrm{g})$ & $\begin{array}{c}q_{L} \\
(\mathrm{U} / \mathrm{g} \cdot \mathrm{h})\end{array}$ \\
\hline 3.0 & $5.8 \pm 0.0$ & $11.4 \pm 0.1$ & $5.10 \pm 0.78$ & $40.5 \pm 4.2$ & 1.024 & 0.158 & 3.639 & 0.049 \\
\hline 4.0 & $6.5 \pm 0.0$ & $16.4 \pm 0.2$ & $6.86 \pm 0.63$ & $58.0 \pm 4.5$ & 1.310 & 0.227 & 4.496 & 0.049 \\
\hline 5.0 & $6.6 \pm 0.0$ & $16.2 \pm 0.3$ & $8.90 \pm 0.88$ & $79.5 \pm 5.0$ & 1.205 & 0.225 & 5.915 & 0.068 \\
\hline 6.0 & $6.6 \pm 0.1$ & $18.9 \pm 0.1$ & $13.82 \pm 0.44$ & $100.0 \pm 3.0$ & 1.312 & 0.262 & 6.807 & 0.073 \\
\hline 7.0 & $7.0 \pm 0.1$ & $14.8 \pm 0.9$ & $3.83 \pm 0.38$ & $33.0 \pm 2.2$ & 1.329 & 0.205 & 2.320 & 0.031 \\
\hline 8.0 & $7.6 \pm 0.0$ & $15.4 \pm 0.1$ & $2.33 \pm 0.22$ & $21.2 \pm 0.7$ & 1.127 & 0.214 & 1.618 & 0.019 \\
\hline 9.0 & $7.9 \pm 0.1$ & $15.0 \pm 0.4$ & $2.47 \pm 0.37$ & $19.7 \pm 2.7$ & 1.469 & 0.208 & 1.934 & 0.018 \\
\hline 10.0 & $8.1 \pm 0.0$ & $14.7 \pm 0.5$ & $2.47 \pm 0.26$ & $22.0 \pm 1.7$ & 1.577 & 0.204 & 2.364 & 0.020 \\
\hline
\end{tabular}

Culture conditions: Vogel's liquid medium with $1.5 \%(\mathrm{w} / \mathrm{v})$ olive oil and $0.2 \%(\mathrm{w} / \mathrm{v})$ yeast extract at $28^{\circ} \mathrm{C}$, agitated at $210 \mathrm{rpm}$, for $72 \mathrm{~h}$. $Y_{X / S}$ : biomass yield on substrate consumed; $Y_{L / S}$ : lipase yield on substrate consumed; $P_{X}$ : biomass productivity; $q_{L}$ : specific rate of lipase production. 


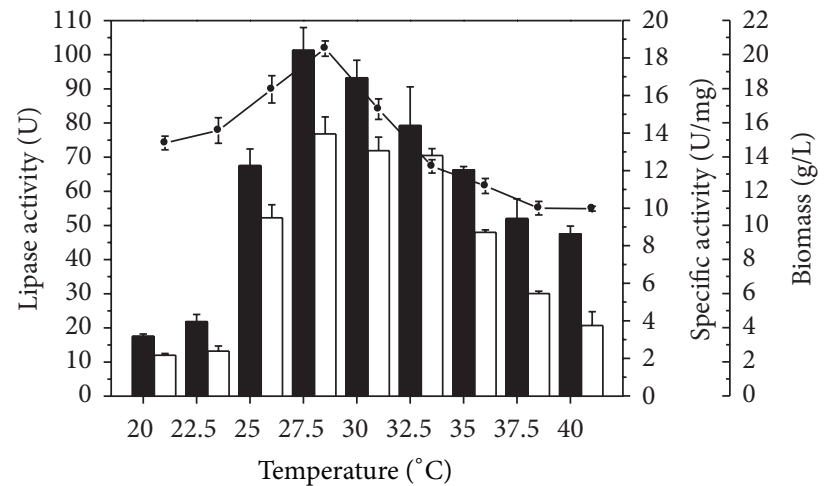

Figure 2: Effect of temperature on growth and lipase production by C. viswanathii. Culture conditions: cultures were carried out in Vogel's medium with $1.5 \%(\mathrm{w} / \mathrm{v})$ olive oil and $0.2 \%(\mathrm{w} / \mathrm{v})$ yeast extract and agitated at $210 \mathrm{rpm}$, at $\mathrm{pH}$ 6.0. (घ) lipase activity, ( $\square$ ) specific activity, and (๑) biomass.

The highest specific activity (13.8 $\mathrm{U} / \mathrm{mg}$ protein) and biomass $(18.9 \mathrm{~g} / \mathrm{L})$ were also verified in these culture conditions. Fermentation parameters analyzed showed high biomass and lipase yields in $\mathrm{pH} 6.0\left(Y_{X / S}=1.312 \mathrm{~g} / \mathrm{g}\right.$ and $Y_{L / S}=6.807 \mathrm{U} / \mathrm{g}$, resp.) as well as specific rate lipase production $\left(q_{L}=0.079 \mathrm{U}\right.$ of lipase/g of biomass.h). Ali et al. [30] reported maximum lipase production by $C$. lipolytica in this same $\mathrm{pH}$. An initial $\mathrm{pH}$ of 4.5 was reported as optimum for lipase production by continuous fermentation of Yarrowia lipolytica [33].

The cultivation temperature ranging from 20 to $40^{\circ} \mathrm{C}$ and its effects in the cell growth and lipase production were also analyzed, maintaining the conditions previously established ( $72 \mathrm{~h}$ cultures, $210 \mathrm{rpm}$, and $\mathrm{pH}$ 6.0). When the incubation temperature was increased, lipase production, specific activity, and cell growth also increased up to $27.5^{\circ} \mathrm{C}$ (Figure 2). The microbial growth at $27.5^{\circ} \mathrm{C}$ corresponded to $20.3 \mathrm{~g} / \mathrm{L}$, decreasing substantially up to $40^{\circ} \mathrm{C}(10.9 \mathrm{~g} / \mathrm{L})$. In this temperature, the values of lipase production and specific activity were $101.2 \mathrm{U}$ and $13.9 \mathrm{U} / \mathrm{mg}$, respectively. Both lipase production and specific activity remained at high levels until $32.5^{\circ} \mathrm{C}$, decreasing significantly after this temperature. The highest biomass and lipase yields as well as maximal biomass $\left(P_{X}=0.282 \mathrm{~g} / \mathrm{h}\right)$, were also observed at $27.5^{\circ} \mathrm{C}\left(Y_{X / S}=\right.$ $1.381 \mathrm{~g} / \mathrm{g}$ and $Y_{L / S}=6.892 \mathrm{U} / \mathrm{g}$ ), (Table 3). However, the highest specific rate of lipase production was at $32.5^{\circ} \mathrm{C}\left(q_{L}=\right.$ $0.079 \mathrm{U}$ of lipase/g of biomass.h) although operational cost is inferior at temperature next to room temperature.

These results are consistent with those observed by Lin et al. [16] which demonstrated that temperature control during submerged cultures is a critical factor that can greatly reduce the productivity of the system even with relatively small variations. C. viswanathii was sensitive to variations of $2.5^{\circ} \mathrm{C}$ for enzyme production and growth. In other studies, several microorganisms were investigated to produce lipase at different temperatures $[26,34]$ and most of them presented optimum temperature for enzyme production between 25 and $30^{\circ} \mathrm{C}[30,35,36]$.
TABLE 3: Fermentations parameters of the C. viswanathii cultures in different temperatures.

\begin{tabular}{lcccc}
\hline Temperature $\left({ }^{\circ} \mathrm{C}\right)$ & $Y_{X / S}(\mathrm{~g} / \mathrm{g})$ & $P_{X}(\mathrm{~g} / \mathrm{h})$ & $Y_{L / S}(\mathrm{U} / \mathrm{g})$ & $\begin{array}{c}q_{L} \\
(\mathrm{U} / \mathrm{g} \cdot \mathrm{h})\end{array}$ \\
\hline 20.0 & 1.230 & 0.193 & 1.435 & 0.016 \\
22.5 & 1.151 & 0.219 & 1.798 & 0.022 \\
25.0 & 1.263 & 0.250 & 4.814 & 0.052 \\
27.5 & 1.381 & 0.282 & 6.892 & 0.070 \\
30.0 & 1.348 & 0.243 & 6.475 & 0.077 \\
32.5 & 1.014 & 0.193 & 5.839 & 0.079 \\
35.0 & 0.882 & 0.173 & 4.853 & 0.070 \\
37.5 & 0.967 & 0.152 & 4.435 & 0.066 \\
40.0 & 1.023 & 0.148 & 4.667 & 0.062 \\
\hline
\end{tabular}

$Y_{X / S}$ : biomass yield on substrate consumed; $Y_{L / S}$ : lipase yield on substrate consumed; $P_{X}$ : biomass productivity; $q_{L}$ : specific rate of lipase production.

\subsection{Effect of Surfactants and Emulsifiers on Lipase Production.} Surfactant or emulsifier addition during the fermentation process has often been shown to enhance extracellular lipase production due to changes in the permeability of the cell or surfactant effects on cell-bound lipase. Nevertheless, surfactants and emulsifiers do not always increase lipase production, and their effects appear to depend on both surfactant and the strain studied [36]. The influence of surfactants Tween 20, Tween 80, and Triton X-100 and emulsifiers gum Arabic, soybean lecithin, and sodium deoxycholate on cell growth and lipase production is presented in Table 4 . Soybean lecithin was the only one that increased lipase production $(147.5 \mathrm{U})$. The parameters, lipase yield $\left(Y_{L / S}=\right.$ $10.061 \mathrm{U} / \mathrm{g})$ and specific rate of lipase production $\left(q_{L}=\right.$ $0.114 \mathrm{U}$ of lipase/g of biomass.h), were considerably superior to the results observed without emulsifier (control). The parameters biomass yield $\left(Y_{X / S}=1.226 \mathrm{~g} / \mathrm{g}\right)$ and biomass productivity $\left(P_{X}=0.250 \mathrm{~g} / \mathrm{h}\right)$ decreased with the addition of this emulsifier. Soybean lecithin is composed of specific phospholipids, triglycerides and other nonphospholipids nontoxic compounds [37], which may have been metabolized by organisms. Other surfactants or emulsifiers used in the culture media show a deleterious effect on lipase production. Triton X-100 greatly reduced lipase and biomass production (5.75 $\mathrm{U}$ and $5.6 \mathrm{~g} / \mathrm{L}$, resp.). Domínguez et al. [36] reported that surfactants did not significantly increase lipase production by Y. lipolytica, but Pogori et al. [38] reported that Rhizopus chinensis lipase production decreased when surfactants were added to the culture medium.

\section{Biochemical Characterization}

6.1. Effect of $\mathrm{pH}$ on Activity and Stability. The effects of $\mathrm{pH}$ on lipase activity and stability are shown in Figure 3. The lipase activity (100\%) was maximal at $\mathrm{pH} 3.5$ (Figure $3(\mathrm{a})$ ). The activity decreased significantly up to $\mathrm{pH} 5.0$ and slightly from this $\mathrm{pH}$ up to 7.0, reducing markedly from 7.0 to 8.0 . At $\mathrm{pH}$ range 2.0-3.0, lipase activity shows 45 to $53 \%$, respectively. The enzyme was more stable in the $\mathrm{pH}$ range from 4.0 to 5.0 , retaining almost $100 \%$ of activity after $24 \mathrm{~h}$. At $\mathrm{pH}$ range 
TABLE 4: Effect of the surfactants and emulsifiers on growth and lipase production by C. viswanathii.

\begin{tabular}{|c|c|c|c|c|c|c|c|}
\hline Emulsifiers $(0.1 \%, \mathrm{w} / \mathrm{v})$ & $\begin{array}{c}\text { Lipase activity } \\
(\mathrm{U})\end{array}$ & $\begin{array}{c}\text { Specific activity } \\
\text { (U/mg prot) }\end{array}$ & $\begin{array}{c}\text { Biomass } \\
(\mathrm{g} / \mathrm{L})\end{array}$ & $Y_{X / S}(\mathrm{~g} / \mathrm{g})$ & $P_{X}(\mathrm{~g} / \mathrm{h})$ & $Y_{L / S}(\mathrm{U} / \mathrm{g})$ & $q_{L}(\mathrm{U} / \mathrm{g} \cdot \mathrm{h})$ \\
\hline $\begin{array}{l}\text { Control (no surfactant } \\
\text { or emulsifier) }\end{array}$ & $100.00 \pm 3.00$ & $13.82 \pm 0.44$ & $18.90 \pm 0.92$ & 1.456 & 0.303 & 6.638 & 0.062 \\
\hline Tween 20 & $77.50 \pm 7.75$ & $11.31 \pm 1.14$ & $17.81 \pm 0.91$ & 1.231 & 0.247 & 5.360 & 0.060 \\
\hline Tween 80 & $32.50 \pm 2.75$ & $5.07 \pm 0.45$ & $16.60 \pm 0.85$ & 1.164 & 0.230 & 2.280 & 0.027 \\
\hline Triton X-100 & $5.75 \pm 0.50$ & $0.89 \pm 0.08$ & $5.55 \pm 0.62$ & 0.776 & 0.077 & 0.804 & 0.014 \\
\hline Gum Arabic & $65.00 \pm 5.25$ & $1.53 \pm 0.16$ & $16.83 \pm 0.30$ & 1.408 & 0.233 & 5.439 & 0.055 \\
\hline Soybean lecithin & $147.50 \pm 4.25$ & $2.33 \pm 0.74$ & $17.97 \pm 0.36$ & 1.226 & 0.250 & 10.061 & 0.114 \\
\hline Sodium deoxycholate & $52.50 \pm 4.25$ & $0.52 \pm 0.04$ & $14.11 \pm 1.04$ & 1.033 & 0.196 & 3.849 & 0.051 \\
\hline
\end{tabular}

Culture conditions: Vogel's liquid medium with $1.5 \%(\mathrm{w} / \mathrm{v})$ olive oil and $0.2 \%(\mathrm{w} / \mathrm{v})$ yeast extract at $28^{\circ} \mathrm{C}$, agitated at $210 \mathrm{rpm}, \mathrm{pH} 6.0$, for $72 \mathrm{~h} . Y_{X / \mathrm{s}}$ : biomass yield on substrate consumed; $Y_{L / S}$ : lipase yield on substrate consumed; $P_{X}$ : biomass productivity; $q_{L}$ : specific rate of lipase production.

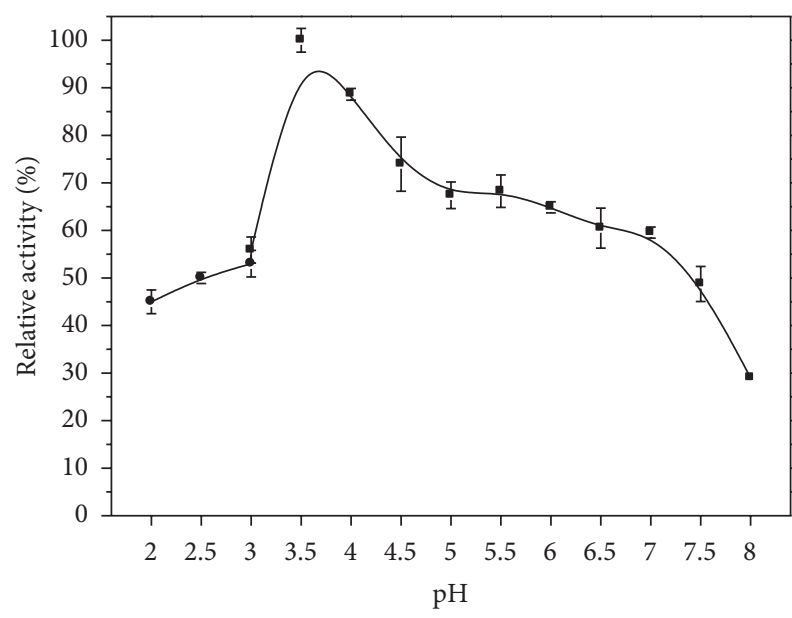

(a)

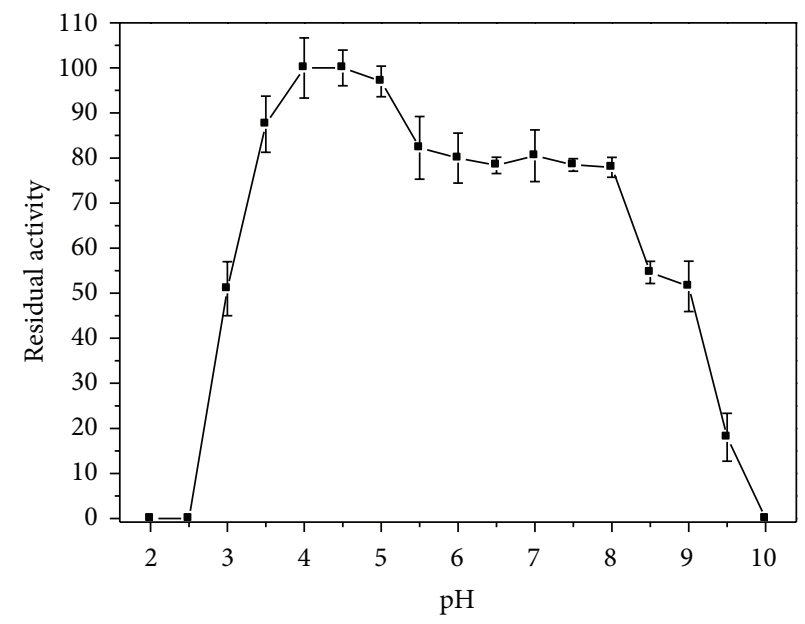

(b)

FIGURE 3: Optimal pH (a) and pH stability (b) of the crude C. viswanathii lipase. Assay conditions: $0.05 \mathrm{M}$ glycine- $\mathrm{HCl}$ buffer from 2.0 to 3.0 , McIlvaine buffer from 3.0 to 8.0 , and $0.05 \mathrm{M}$ glycine- $\mathrm{NaOH}$ from 8.0 to 10 . Lipase activity assays were carried out at $37^{\circ} \mathrm{C}$ (a) and in $\mathrm{McIlvaine}$ buffer $\mathrm{pH} 3.5$, at $37^{\circ} \mathrm{C}(\mathrm{b})$.

from 5.5 to 8.0 the residual activity remained around $80 \%$ (Figure 3(b)). Residual activity remained above $50 \%$ at $\mathrm{pH}$ 3.0 and at 8.5-9.0; however, at $\mathrm{pH}$ range from 2.0 to 2.5 and 10.0 the enzyme was completely inactivated.

The optimum acid $\mathrm{pH}$ of $\mathrm{C}$. viswanathii lipase activity is different from other Candida lipases that presented optimal $\mathrm{pH}$ range in alkaline conditions. Candida rugosa lipase had optimal activity at $\mathrm{pH} 7.5$ [39]. Lipase from Candida antarctica showed the highest activity at $\mathrm{pH} 8.0$ and the enzyme was stable at $\mathrm{pH}$ range of 7.0-9.0 after $24 \mathrm{~h}$ [40]. Candida cylindracea lipases A and B showed similar $\mathrm{pH}$ profiles using tributyrin as substrate, with optimum activity around $\mathrm{pH}$ 7.0. However, the decrease in activity at $\mathrm{pH} 8.0$ was more pronounced in lipase $\mathrm{B}$, whereas lipase $\mathrm{A}$ was less active at pH 5.0 [41]. An acid lipase with optimal activity at pH 2.5 was produced by Aspergillus niger NCIM 1207 [42]. The lipolytic activity of this strain decreased significantly when the $\mathrm{pH}$ was increased to 4.0 and its stability at alkaline $\mathrm{pH}$ range of $8.0-11.0$ retained $100 \%$ of its original activity after incubation for $24 \mathrm{~h}$. Maximal activity of Pseudomonas gessardii lipase produced with beef tallow was observed at $\mathrm{pH} 5.0$; however above $\mathrm{pH}$ 7.0, the activity rapidly decreased, retaining $33 \%$ of its activity at $\mathrm{pH} 9.0$ [43]. This enzyme was also produced using slaughterhouse waste showing maximum $\mathrm{pH}$ activity at 3.5 and stability between $\mathrm{pH} 2.5$ and $\mathrm{pH} 5.5$ [44].

\subsection{Effect of Temperature on Activity and Thermal Stability.} C. viswanathii lipase activity increased with temperature from $25^{\circ} \mathrm{C}$ up to $40^{\circ} \mathrm{C}$ (Figure $4(\mathrm{a})$ ). The highest activity was observed at $40^{\circ} \mathrm{C}(100 \%)$, and elevated activity was also found at $45^{\circ} \mathrm{C}(96.3 \%)$ and $50^{\circ} \mathrm{C}(87.2 \%)$. Lipase activity rapidly reduced to $32.8 \%$ at $60^{\circ} \mathrm{C}$ and retained $56.9 \%$ of its activity at temperature of $25^{\circ} \mathrm{C}$. Most fungal lipases present maximal activity at temperatures ranging from 30 to $60^{\circ} \mathrm{C}$. C. antarctica lipase showed optimum activity at $35^{\circ} \mathrm{C}$ [40]. Mateos Diaz et al. [45] showed that the maximal activity of the lipase produced by Rhizopus homothallicus in submerged fermentation or solid state fermentation differed between 30 and $40^{\circ} \mathrm{C}$. Fusarium oxysporum produced an alkaline lipase with maximum activity at $50^{\circ} \mathrm{C}$ [46]. The highest lipolytic activity against $\rho$ NPP of the Penicillium aurantiogriseum was observed at $60^{\circ} \mathrm{C}$ [47]. 


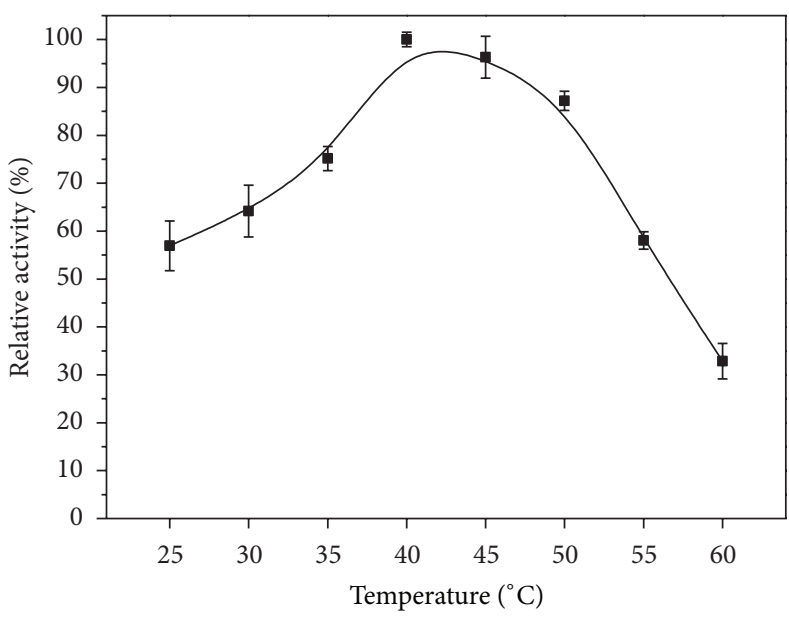

(a)

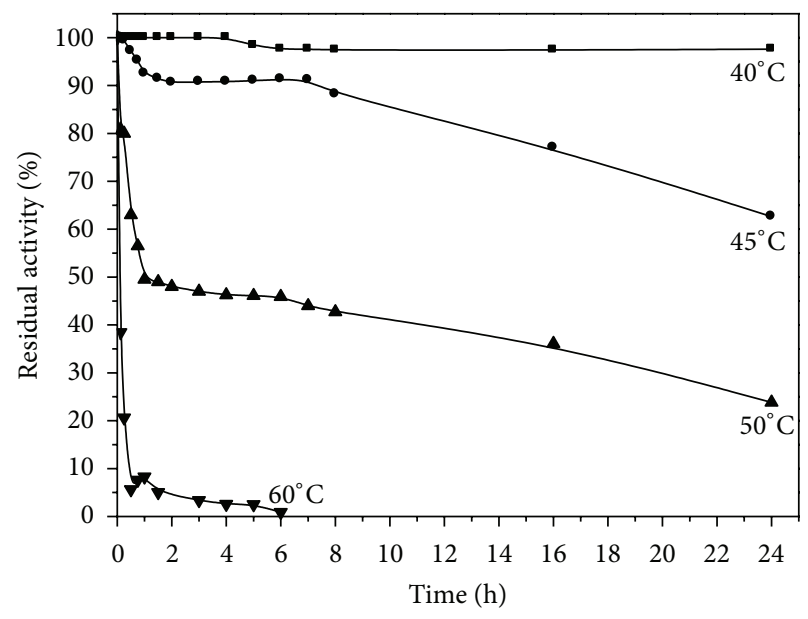

(b)

FIGURE 4: Optimal temperature (a) and thermal stability (b) of the crude C. viswanathii lipase. Assay conditions: McIlvaine buffer pH 3.5 (a). The enzymatic preparation was incubated at (ロ $40,(\bullet) 45$, and $(\boldsymbol{\Delta}) 50^{\circ} \mathrm{C}$, without substrate. The residual lipase activity was assayed with McIlvaine buffer, $\mathrm{pH} 3.5$, at $40^{\circ} \mathrm{C}(\mathrm{b})$.

The crude C. viswanathii lipase retained $99.8 \%$ of its activity after $24 \mathrm{~h}$ at $40^{\circ} \mathrm{C}$ (Figure $4(\mathrm{~b})$ ), showing $66.9 \%$ of its activity after $72 \mathrm{~h}$ (data not shown). At $45^{\circ} \mathrm{C}, 62.6 \%$ of lipase activity was recovered after $24 \mathrm{~h}$, while, at $50^{\circ} \mathrm{C}, 50 \%$ of residual activity was observed after $0.9 \mathrm{~h}$. The enzyme was not stable at temperature of $60^{\circ} \mathrm{C}$, and only $8.3 \%$ residual activity was verified after $1 \mathrm{~h}$ of incubation. Purified C. antarctica lipase showed optimal activity at $35^{\circ} \mathrm{C}$ and maximal stability at $30^{\circ} \mathrm{C}$. This enzyme showed a rapid decrease in activity at $45^{\circ} \mathrm{C}$, after $1 \mathrm{~h}$ of incubation [40]. Ramani et al. [44] suggested that the thermal stability at comparatively higher temperature may be due to the influence of factors such as broad $\mathrm{pH}$ stability, metal ions, and the rigidity in the lipase structure.

6.3. Effects of Organic Solvents on Lipase Activity. Lipase stability in organic solvents is an essential prerequisite for lipase applications in organic synthesis [48], since synthetic reactions with enzymes are often performed in organic solvents to shift the thermodynamic equilibrium toward synthesis [49]. C. viswanathii lipase activity was determined after addition of polar organic solvents in the reaction at final concentration of $1 \%(\mathrm{v} / \mathrm{v})$ and $10 \%(\mathrm{v} / \mathrm{v})$ (Table 5). At $1 \%(\mathrm{v} / \mathrm{v})$ concentration, methanol, ethanol, 1-propanol, and DMSO had no effect on lipase activity. In the presence of acetonitrile, acetone, isopropanol, and 2-propanol at 1\%, C. viswanathii lipase retained approximately $90 \%$ of its activity. At $10 \%$ (v/v), methanol and DMSO weakly affected the lipase activity and ethanol had a moderate effect under this condition. However, isopropanol, acetone, 2-propanol, 1-propanol, and acetonitrile drastically reduced the lipase activity. Ogino and Ishikawa [50] reported that direct contact of a polar organic solvent in monophasic systems with an enzyme can result in severe enzyme structure distortion, rapid denaturation, and even complete inactivation.

6.4. Effect of Substances and Surfactants on Lipase Stability. The effect of different metal ions and surfactants on the
TABLE 5: Effect of organic solvents on lipase activity produced by $C$. viswanathii.

\begin{tabular}{lccc}
\hline Organic solvents & Log $P$ values & \multicolumn{2}{c}{ Relative activity (\%) } \\
& & $1 \%$ & $10 \%$ \\
\hline $\begin{array}{l}\text { Control (no organic } \\
\text { solvent added) }\end{array}$ & & $100 \pm 4.5$ & $100 \pm 5.6$ \\
DMSO & -1.378 & $98.9 \pm 6.9$ & $91.8 \pm 6.2$ \\
Methanol & -0.764 & $102.6 \pm 5.9$ & $94.0 \pm 5.3$ \\
Acetonitrile & -0.394 & $89.8 \pm 7.1$ & $16.8 \pm 5.2$ \\
Ethanol & -0.235 & $101.9 \pm 6.2$ & $60.0 \pm 7.5$ \\
Acetone & -0.208 & $88.0 \pm 5.4$ & $31.8 \pm 4.9$ \\
1-Propanol & 0.250 & $109.1 \pm 9.1$ & $18.6 \pm 9.7$ \\
Isopropanol & 0.074 & $91.1 \pm 6.3$ & $32.4 \pm 5.4$ \\
2-Propanol & 0.070 & $88.1 \pm 6.5$ & $29.2 \pm 9.5$ \\
\hline
\end{tabular}

Assay conditions: lipase activities were assayed on $p$ NPP hydrolysis using Mcllvaine buffer $\mathrm{pH} 3.5$, at $40^{\circ} \mathrm{C}$. $\log P: \operatorname{logarithm}$ of the partition coefficient $(P)$ in octanol/water two-phase system indicates the solvents hydrophobicity. DMSO: dimethylsulfoxide.

activity of the lipase is shown in Table 6. Among the metal ions assayed, only $\mathrm{NaCl}$ increased the activity at $10 \mathrm{mM}$ and $20 \mathrm{mM}$ (110.4\% and 117.4\%, resp.), whereas $\mathrm{MgSO}_{4}, \mathrm{BaCl}_{2}$, $\mathrm{NH}_{4} \mathrm{Cl}$, and $\mathrm{CaCl}_{2}$ had no significant effect on the activity. Usually, fungal lipases can be activated by adding $\mathrm{Mg}^{2+}, \mathrm{Ca}^{2+}$, $\mathrm{NH}_{4}$, and $\mathrm{Ba}^{2+}$ ions to the reaction media $[45,51]$. However, the crude $C$. viswanathii lipase was not activated by these ions. $\mathrm{ZnSO}_{4}$ and $\mathrm{CoCl}_{2}$ inhibited the activity of both 10 and $20 \mathrm{mM}$. $\mathrm{ZnSO}_{4}$ was previously reported as an inhibitor of lipase from Penicillium sp. [14], whereas $\mathrm{CoCl}_{2}$ inhibited the lipase from Rhizopus homothallicus [45]. The addition of the chelating agent EDTA did not affect enzyme activity, indicating that $C$. viswanathii lipase is not a metalloenzyme as reported for other lipases such as those from Penicillium sp. [14] and Aspergillus awamori [52]. 
TABLE 6: Effect of substances on Candida viswanathii lipase stability.

\begin{tabular}{|c|c|c|}
\hline \multirow[b]{2}{*}{ Substances } & \multicolumn{2}{|c|}{ Relative activity (\%) } \\
\hline & $10 \mathrm{mM}$ & $20 \mathrm{mM}$ \\
\hline Control (no substance added) & $100 \pm 4.8$ & $100 \pm 4.8$ \\
\hline $\mathrm{ZnSO}_{4}$ & $84.4 \pm 3.6$ & $60.0 \pm 10.0$ \\
\hline $\mathrm{MgSO}_{4}$ & $99.9 \pm 3.9$ & $96.5 \pm 4.0$ \\
\hline $\mathrm{BaCl}_{2}$ & $106.7 \pm 3.6$ & $98.6 \pm 3.7$ \\
\hline $\mathrm{CoCl}_{2}$ & $60.8 \pm 7.4$ & $42.7 \pm 1.0$ \\
\hline $\mathrm{NaCl}$ & $110.4 \pm 5.9$ & $117.4 \pm 6.8$ \\
\hline $\mathrm{NH}_{4} \mathrm{Cl}$ & $106.8 \pm 4.2$ & $104.4 \pm 3.74$ \\
\hline $\mathrm{Pb}\left(\mathrm{CH}_{3} \mathrm{COO}\right)_{2}$ & $95.1 \pm 5.0$ & $94.2 \pm 6.3$ \\
\hline $\mathrm{CaCl}_{2}$ & $103.2 \pm 4.4$ & $96.6 \pm 4.9$ \\
\hline EDTA & $103.7 \pm 4.2$ & $98.6 \pm 6.1$ \\
\hline Emulsifiers & $1 \%$ & $5 \%$ \\
\hline SDS & ND & ND \\
\hline Tween 20 & $88.2 \pm 9.5$ & $52.5 \pm 4.9$ \\
\hline Tween 80 & $93.8 \pm 8.6$ & $60.5 \pm 5.8$ \\
\hline Triton X-100 & $30.3 \pm 6.7$ & $26.9 \pm 8.7$ \\
\hline Gum Arabic & $107.3 \pm 4.8$ & $102.0 \pm 5.1$ \\
\hline
\end{tabular}

Assay conditions: lipase activities were assayed on $p$ NPP hydrolysis after $1 \mathrm{~h}$ of incubation using McIlvaine buffer $\mathrm{pH} 3.5$, at $40^{\circ} \mathrm{C}$, without substrate.

Lipase activity was not affected by gum Arabic. In the presence of Tween 80 , the highest inhibition was observed at $5 \%(60.5 \%)$. Tween 20 at $1 \%$ and $5 \%$ inhibited the activity to $88.2 \%$ and $52.5 \%$, respectively. SDS completely inactivated the enzyme and Triton X-100 was a strong lipase inhibitor, reducing the activity to $30.3 \%$ and $26.9 \%$ at both concentrations. The lipase from A. awamori was also inhibited by nonionic detergents [52]. The inhibition of the lipase by an ionic surfactant, such as SDS, can be due the formation of complexes with protein in solution altering the conformational stability and the hydrophobicity of the protein surface. Additionally, partial or complete unfolding of the tertiary protein structure can be affected, due to additional hydrophobic interaction [53].

6.5. Hydrolytic Activity on Triacylglycerols. The hydrolytic activity of the lipase on pure and natural triacylglycerols is shown in Figure 5. The highest hydrolytic activity was observed for triolein (100\%), olive oil (85.7\%), palm oil (83.3\%), soybean oil (78.6\%), canola oil, castor oil (69.0\%), and sunflower oil (64.3\%). Intermediary hydrolytic activity was observed for poultry fat (59.5\%), lard (54.8\%), and maize oil (50.0\%). Crude C. viswanathii lipase showed the lowest activity on tributyrin (45.5\%). These results suggest that this enzyme is more active on triacylglycerol with long chain fatty acids being capable of hydrolyzing a broad spectrum of esters of fatty acid chain lengths. Similar results were found for lipases from Penicillium camembertii [54], Colletotrichum gloeosporioides [55], and Pseudomonas gessardii [43].

\section{Concluding Remarks}

The present study demonstrated the importance of controlling physical parameters for lipase production by

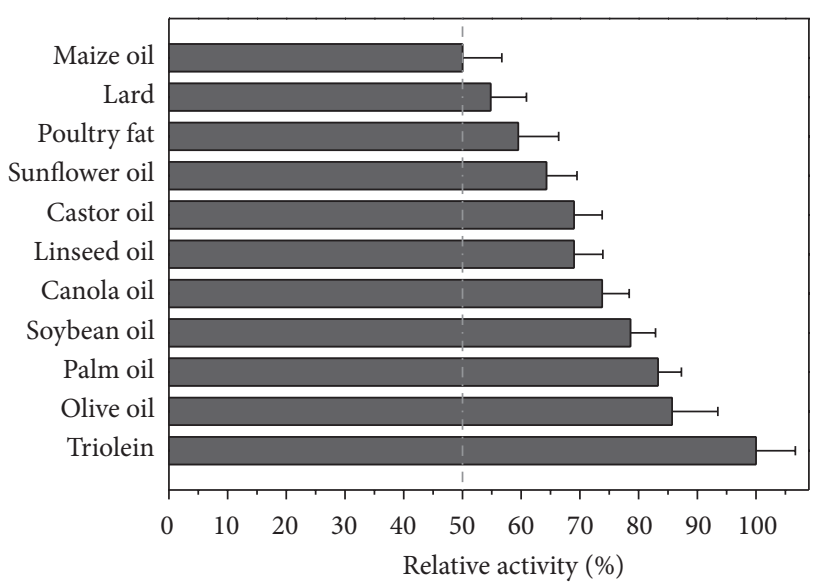

FIgURE 5: Hydrolysis of triacylglycerols by crude Candida viswanathii lipase. Assay conditions: triacylglycerols hydrolysis was carried out in McIlvaine buffer $\mathrm{pH} 4.0$ with $5 \%$ (w/v) Triton X-100 and hydrolysis activities were assayed by titration method.

C. viswanathii. Agitation speed, temperature, and initial $\mathrm{pH}$ are essential to produce $101 \mathrm{U} / \mathrm{L}$ of crude lipase. The lipase production was even more increased by supplementation with soybean lecithin. The biochemical characterization of the crude C. viswanathii lipase revealed that this enzyme shows different properties when compared to those from other Candida spp. Optimal activity at acid pH of 3.5 suggests a new lipolytic enzyme for this genus and for yeast in general. In addition, crude lipase presented high stability in acid conditions and was highly stable at 40 and $45^{\circ} \mathrm{C}$, remaining active in the presence of organic solvents as DMSO and methanol. The enzyme was not activated by metal ions and the activity was preserved in the presence of gum Arabic for $1 \mathrm{~h}$ at $40^{\circ} \mathrm{C}$. C. viswanathii lipase presented a broad specificity for triacylglycerols hydrolysis suggesting that this enzyme can be applied in lipid digestion and biotransformation.

\section{Conflict of Interests}

The authors declare that there is no conflict of interests regarding the publication of this paper.

\section{Acknowledgment}

The authors would like to thank the National Council of Technological and Scientific Development (CNPq) for the financial support and for the scholarship awarded to the first author.

\section{References}

[1] A. Houde, A. Kademi, and D. Leblanc, "Lipases and their industrial applications: an overview," Applied Biochemistry and Biotechnology Part A, vol. 118, no. 1-3, pp. 155-170, 2004.

[2] M. M. C. Feltes, D. de Oliveira, J. M. Block, and J. L. Ninow, “The production, benefits, and applications of monoacylglycerols and diacylglycerols of nutritional interest," Food and Bioprocess Technology, vol. 6, pp. 17-35, 2013. 
[3] E. Rigo, J. L. Ninow, S. M. Tsai et al., "Preliminary characterization of novel extra-cellular lipase from Penicillium crustosum under solid-state fermentation and its potential application for triglycerides hydrolysis," Food and Bioprocess Technology, vol. 5, pp. 1592-1600, 2012.

[4] R. Fernandez-Lafuente, "Lipase from Thermomyces lanuginosus: uses and prospects as an industrial biocatalyst," Journal of Molecular Catalysis B, vol. 62, no. 3-4, pp. 197-212, 2010.

[5] N. Li and M.-H. Zong, "Lipases from the genus Penicillium: production, purification, characterization and applications," Journal of Molecular Catalysis B, vol. 66, no. 1-2, pp. 43-54, 2010.

[6] R. Sharma, Y. Chisti, and U. C. Banerjee, "Production, purification, characterization, and applications of lipases," Biotechnology Advances, vol. 19, no. 8, pp. 627-662, 2001.

[7] A. Salihu, M. Z. Alam, M. I. AbdulKarim, and H. M. Salleh, "Lipase production: an insight in the utilization of renewable agricultural residues," Resources, Conservation and Recycling, vol. 58, pp. 36-44, 2012.

[8] F. J. Contesini, D. B. Lopes, G. A. MacEdo, M. D. G. Nascimento, and P. D. O. Carvalho, "Aspergillus sp. lipase: potential biocatalyst for industrial use," Journal of Molecular Catalysis B, vol. 67, no. 3-4, pp. 163-171, 2010.

[9] F. Hasan, A. A. Shah, and A. Hameed, "Methods for detection and characterization of lipases: a comprehensive review," Biotechnology Advances, vol. 27, no. 6, pp. 782-798, 2009.

[10] H. Treichel, D. de Oliveira, M. A. Mazutti, M. Di Luccio, and J. V. Oliveira, "A review on microbial lipases production," Food and Bioprocess Technology, vol. 3, no. 2, pp. 182-196, 2010.

[11] P. Fickers, J. M. Nicaud, C. Gaillardin, J. Destain, and P. Thonart, "Carbon and nitrogen sources modulate lipase production in the yeast Yarrowia lipolytica," Journal of Applied Microbiology, vol. 96, no. 4, pp. 742-749, 2004.

[12] S. Papanikolaou, I. Chevalot, M. Galiotou-Panayotou, M. Komaitis, I. Marc, and G. Aggelis, "Industrial derivative of tallow: a promising renewable substrate for microbial lipid, single-cell protein and lipase production by Yarrowia lipolytica," Electronic Journal of Biotechnology, vol. 10, no. 3, pp. 425-435, 2007.

[13] S. Dutta and L. Ray, "Production and characterization of an alkaline thermostable crude lipase from an isolated strain of Bacillus cereus C7," Applied Biochemistry and Biotechnology, vol. 159, no. 1, pp. 142-154, 2009.

[14] D. S. Dheeman, S. Antony-Babu, J. M. Frías, and G. T. M. Henehan, "Purification and characterization of an extracellular lipase from a novel strain Penicillium sp. DS-39 (DSM 23773)," Journal of Molecular Catalysis B, vol. 72, no. 3-4, pp. 256-262, 2011.

[15] M. Elibol and D. Ozer, "Influence of oxygen transfer on lipase production by Rhizopus arrhizus," Process Biochemistry, vol. 36, no. 4, pp. 325-329, 2000.

[16] E.-S. Lin, C.-C. Wang, and S.-C. Sung, "Cultivating conditions influence lipase production by the edible Basidiomycete Antrodia cinnamomea in submerged culture," Enzyme and Microbial Technology, vol. 39, no. 1, pp. 98-102, 2006.

[17] A. Salihu, M. Z. Alam, M. I. Abdulkarim, and H. M. Salleh, "Effect of process parameters on lipase production by Candida cylindracea in stirred tank bioreactor using renewable palm oil mill effluent based medium," Journal of Molecular Catalysis B, vol. 72, no. 3-4, pp. 187-192, 2011.

[18] R. M. De La Casa, J. V. Sinisterra, and J. M. Sánchez-Montero, "Characterization and catalytic properties of a new crude lipase from C. rugosa," Enzyme and Microbial Technology, vol. 38, no. 5, pp. 599-609, 2006.

[19] P. Gupta, L. S. B. Upadhyay, and R. Shrivastava, "Lipase catalyzed-transesterification of vegetable oils by lipolytic bacteria," Research Journal of Microbiology, vol. 6, no. 3, pp. 281-288, 2011.

[20] A. F. Almeida, S. M. Taulk-Tornisielo, and E. C. Carmona, "Influence of carbon and nitrogen sources on lipase production by a newly isolated Candida viswanathii strain," Annals of Biotechnology, 2012.

[21] J. Yang, Y. Koga, H. Nakano, and T. Yamane, "Modifying the chain-length selectivity of the lipase from Burkholderia cepacia KWI-56 through in vitro combinatorial mutagenesis in the substrate-binding site," Protein Engineering, vol. 15, no. 2, pp. 147-152, 2002.

[22] O. H. Lowry, N. J. Rosebrough, A. L. Farr, and R. J. Randal, "Protein measurement with the Folin phenol reagent," The Journal of Biological Chemistry, vol. 193, no. 1, pp. 265-275, 1951.

[23] M. S. Puthli, V. K. Rathod, and A. B. Pandit, "Optimization of lipase production in a triple impeller bioreactor," Biochemical Engineering Journal, vol. 27, no. 3, pp. 287-294, 2006.

[24] S. Takaç, A. E. Ünlü, and B. Erdem, "Oxygen transfer strategy modulates the productions of lipase and esterase enzymes by Candida rugosa," Journal of Molecular Catalysis B, vol. 64, no. 3-4, pp. 150-154, 2010.

[25] S. V. Kamzolova, I. G. Morgunov, A. Aurich et al., "Lipase secretion and citric acid production in Yarrowia lipolytica yeast grown on animal and vegetable fat," Food Technology and Biotechnology, vol. 43, no. 2, pp. 113-122, 2005.

[26] F. Darvishi, I. Nahvi, H. Zarkesh-Esfahani, and F. Momenbeik, "Effect of plant oils upon lipase and citric acid production in Yarrowia lipolytica yeast," Journal of Biomedicine and Biotechnology, vol. 2009, Article ID 562943, 2009.

[27] A. Dominguez, L. Pastrana, M. A. Longo, M. L. Rúa, and M. A. Sanroman, "Lipolytic enzyme production by Thermus thermophilus HB27 in a stirred tank bioreactor," Biochemical Engineering Journal, vol. 26, no. 2-3, pp. 95-99, 2005.

[28] V. Brozzoli, S. Crognale, I. Sampedro, F. Federici, A. D’Annibale, and M. Petruccioli, "Assessment of olive-mill wastewater as a growth medium for lipase production by Candida cylindracea in bench-top reactor," Bioresource Technology, vol. 100, no. 13, pp. 3395-3402, 2009.

[29] R. Gulati, R. K. Saxena, and R. Gupta, "Fermentation and downstream processing of lipase from Aspergillus terreus," Process Biochemistry, vol. 36, no. 1-2, pp. 149-155, 2000.

[30] S. Ali, H. Rafi, and I.-U. Ikram-Ul-Haq, "Production of an extracellular lipase from Candida lipolytica and parameter significance analysis by Plackett-Burman design," Engineering in Life Sciences, vol. 10, no. 5, pp. 465-473, 2010.

[31] H.-R. Kim, I. N.-H. Kim, C. T. Hou, K.-I. L. Kwon, and B.S. Shin, "Production of a novel cold-active lipase from Pichia lynferdii Y-7723," Journal of Agricultural and Food Chemistry, vol. 58, no. 2, pp. 1322-1326, 2010.

[32] R. Sangeetha, A. Geetha, and I. Arulpandi, "Pongamia pinnata seed cake: a promising and inexpensive substrate for production of protease and lipase from Bacillus pumilus SG2 on solid-state fermentation," Indian Journal of Biochemistry and Biophysics, vol. 48, no. 6, pp. 435-439, 2011.

[33] F. J. Deive, M. A. Sanromán, and M. A. Longo, "A comprehensive study of lipase production by Yarrowia lipolytica CECT 1240 (ATCC 18942): from shake flask to continuous bioreactor," 
Journal of Chemical Technology and Biotechnology, vol. 85, no. 2, pp. 258-266, 2010.

[34] H. Yu, J. Han, N. Li, X. Qie, and Y.-M. Jia, "Fermentation performance and characterization of cold-adapted lipase produced with Pseudomonas Lip35," Agricultural Sciences in China, vol. 8, no. 8, pp. 956-962, 2009.

[35] R. Kumar, S. Mahajan, A. Kumar, and D. Singh, "Identification of variables and value optimization for optimum lipase production by Bacillus pumilus RK31 using statistical methodology," New Biotechnology, vol. 28, no. 1, pp. 65-71, 2011.

[36] A. Domínguez, F. J. Deive, M. A. Sanromán, and M. A. Longo, "Effect of lipids and surfactants on extracellular lipase production by Yarrowia lipolytica," Journal of Chemical Technology and Biotechnology, vol. 78, no. 11, pp. 1166-1170, 2003.

[37] C. R. Scholfield, "Composition of soybean lecithin," Journal of the American Oil Chemists Society, vol. 58, no. 10, pp. 889-892, 1981.

[38] N. Pogori, A. Cheikhyoussef, Y. Xu, and D. Wang, "Production and biochemical characterization of an extracellular lipase from Rhizopus chinensis CCTCC M201021," Biotechnology, vol. 7, no. 4, pp. 710-717, 2008.

[39] H. T. Khor, N. H. Tan, and C. L. Chua, "Lipase-catalyzed hydrolysis of palm oil," Journal of the American Oil Chemists' Society, vol. 63, no. 4, pp. 538-540, 1986.

[40] M. Adamczak, "Synthesis, properties, and application of lipase from Candida antartica for high yield monoacylglycerol biosynthesis," Polish Journal of Food Nutriton Science, vol. 53, pp. 3-8, 2003.

[41] M. L. Rúa, T. Díaz-Murino, V. M. Fernández, C. Otero, and A. Ballesteros, "Purification and characterization of two distinct lipases from Candida cylindracea," Biochimica et Biophysica Acta, vol. 1156, no. 2, pp. 181-189, 1993.

[42] N. C. Mhetras, K. B. Bastawde, and D. V. Gokhale, "Purification and characterization of acidic lipase from Aspergillus niger NCIM 1207," Bioresource Technology, vol. 100, no. 3, pp. 14861490, 2009.

[43] K. Ramani, L. J. Kennedy, M. Ramakrishnan, and G. Sekaran, "Purification, characterization and application of acidic lipase from Pseudomonas gessardii using beef tallow as a substrate for fats and oil hydrolysis," Process Biochemistry, vol. 45, no. 10, pp. 1683-1691, 2010.

[44] K. Ramani, E. Chockalingam, and G. Sekaran, "Production of a novel extracellular acidic lipase from Pseudomonas gessardii using slaughterhouse waste as a substrate," Journal of Industrial Microbiology and Biotechnology, vol. 37, no. 5, pp. 531-535, 2010.

[45] J. C. Mateos Diaz, J. A. Rodríguez, S. Roussos et al., "Lipase from the thermotolerant fungus Rhizopus homothallicus is more thermostable when produced using solid state fermentation than liquid fermentation procedures," Enzyme and Microbial Technology, vol. 39, no. 5, pp. 1042-1050, 2006.

[46] J. N. Dos Prazeres, J. A. B. Cruz, and G. M. Pastore, "Characterization of alkaline lipase from Fusarium oxysporum and the effect of different surfactants and detergents on the enzyme activity," Brazilian Journal of Microbiology, vol. 37, no. 4, pp. 505-509, 2006.

[47] V. M. G. Lima, N. Krieger, D. A. Mitchell, and J. D. Fontana, "Activity and stability of a crude lipase from Penicillium aurantiogriseum in aqueous media and organic solvents," Biochemical Engineering Journal, vol. 18, no. 1, pp. 65-71, 2004.

[48] N. Doukyu and H. Ogino, "Organic solvent-tolerant enzymes," Biochemical Engineering Journal, vol. 48, no. 3, pp. 270-282, 2010.
[49] D. S. Dheeman, J. M. Frias, and G. T. M. Henehan, "Influence of cultivation conditions on the production of a thermostable extracellular lipase from Amycolatopsis mediterranei DSM 43304," Journal of Industrial Microbiology and Biotechnology, vol. 37, no. 1, pp. 1-17, 2010.

[50] H. Ogino and H. Ishikawa, "Enzymes which are stable in the presence of organic solvents," Journal of Bioscience and Bioengineering, vol. 91, no. 2, pp. 109-116, 2001.

[51] P. Supakdamrongkul, A. Bhumiratana, and C. Wiwat, "Characterization of an extracellular lipase from the biocontrol fungus, Nomuraea rileyi MJ, and its toxicity toward Spodoptera litura," Journal of Invertebrate Pathology, vol. 105, no. 3, pp. 228-235, 2010.

[52] J.-L. Xia, B. Huang, Z.-Y. Nie, and W. Wang, "Production and characterization of alkaline extracellular lipase from newly isolated strain Aspergillus awamori HB-03," Journal of Central South University of Technology, vol. 18, no. 5, pp. 1425-1433, 2011.

[53] V. Delorme, R. Dhouib, S. Canaan, F. Fotiadu, F. Carrière, and J.-F. Cavalier, "Effects of surfactants on lipase structure, activity, and inhibition," Pharmaceutical Research, vol. 28, no. 8, pp. 18311842, 2011.

[54] T. Tan, M. Zhang, J. Xu, and J. Zhang, "Optimization of culture conditions and properties of lipase from Penicillium camembertii Thom PG-3," Process Biochemistry, vol. 39, no. 11, pp. 1495-1502, 2004.

[55] G. Colen, R. G. Junqueira, and T. Moraes-Santos, "Isolation and screening of alkaline lipase-producing fungi from Brazilian savanna soil," World Journal of Microbiology and Biotechnology, vol. 22, no. 8, pp. 881-885, 2006. 

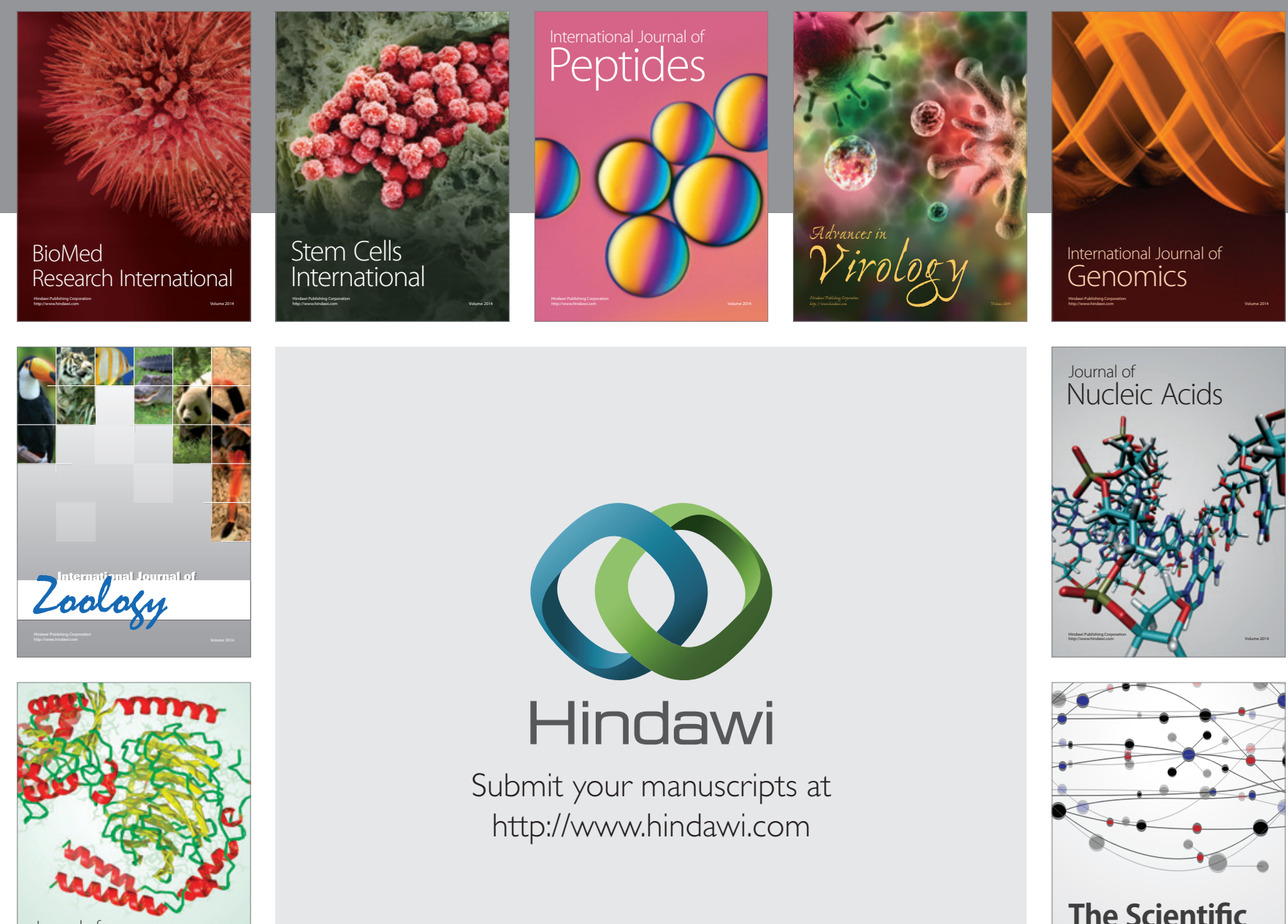

Submit your manuscripts at

http://www.hindawi.com

Journal of
Signal Transduction
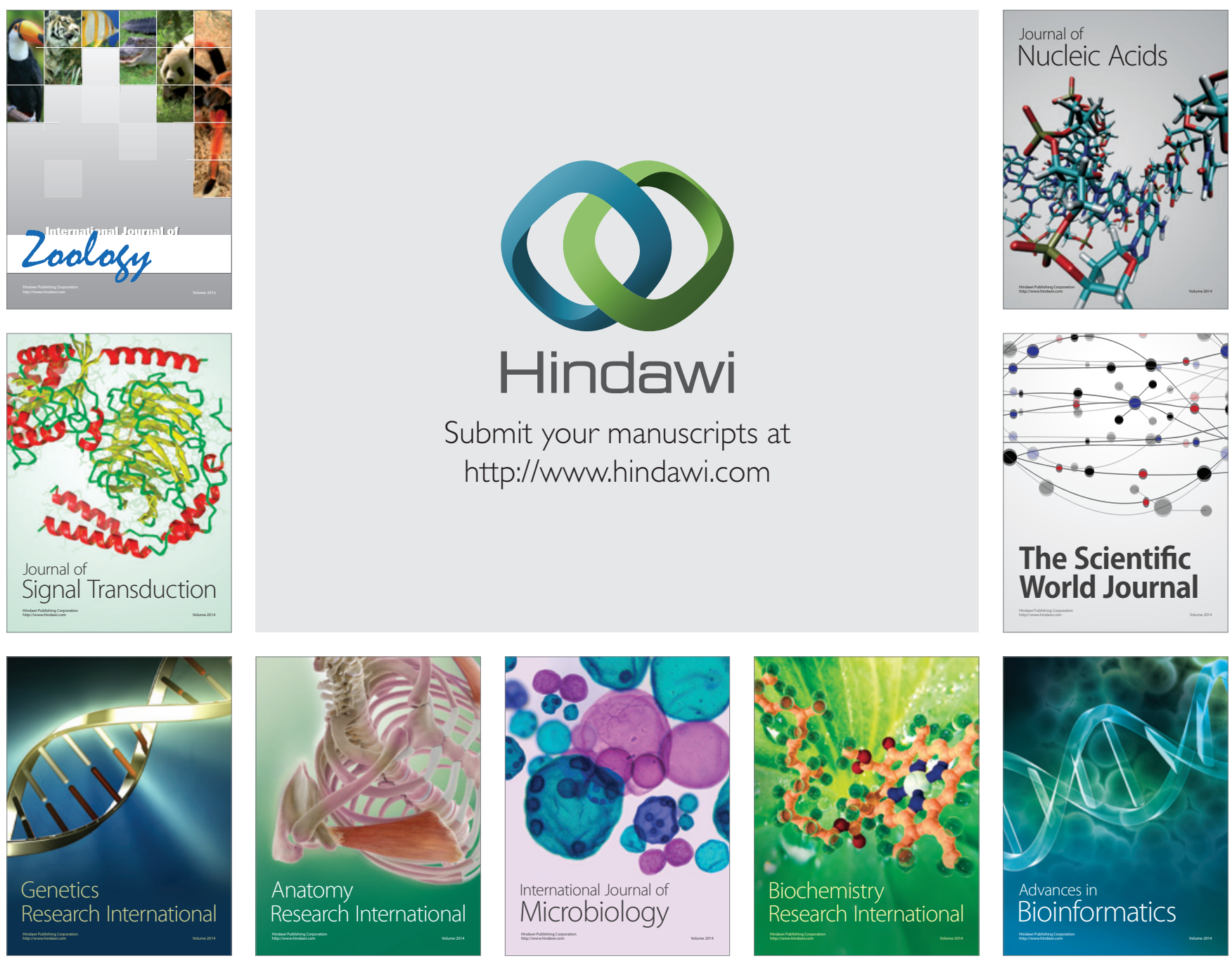

The Scientific World Journal
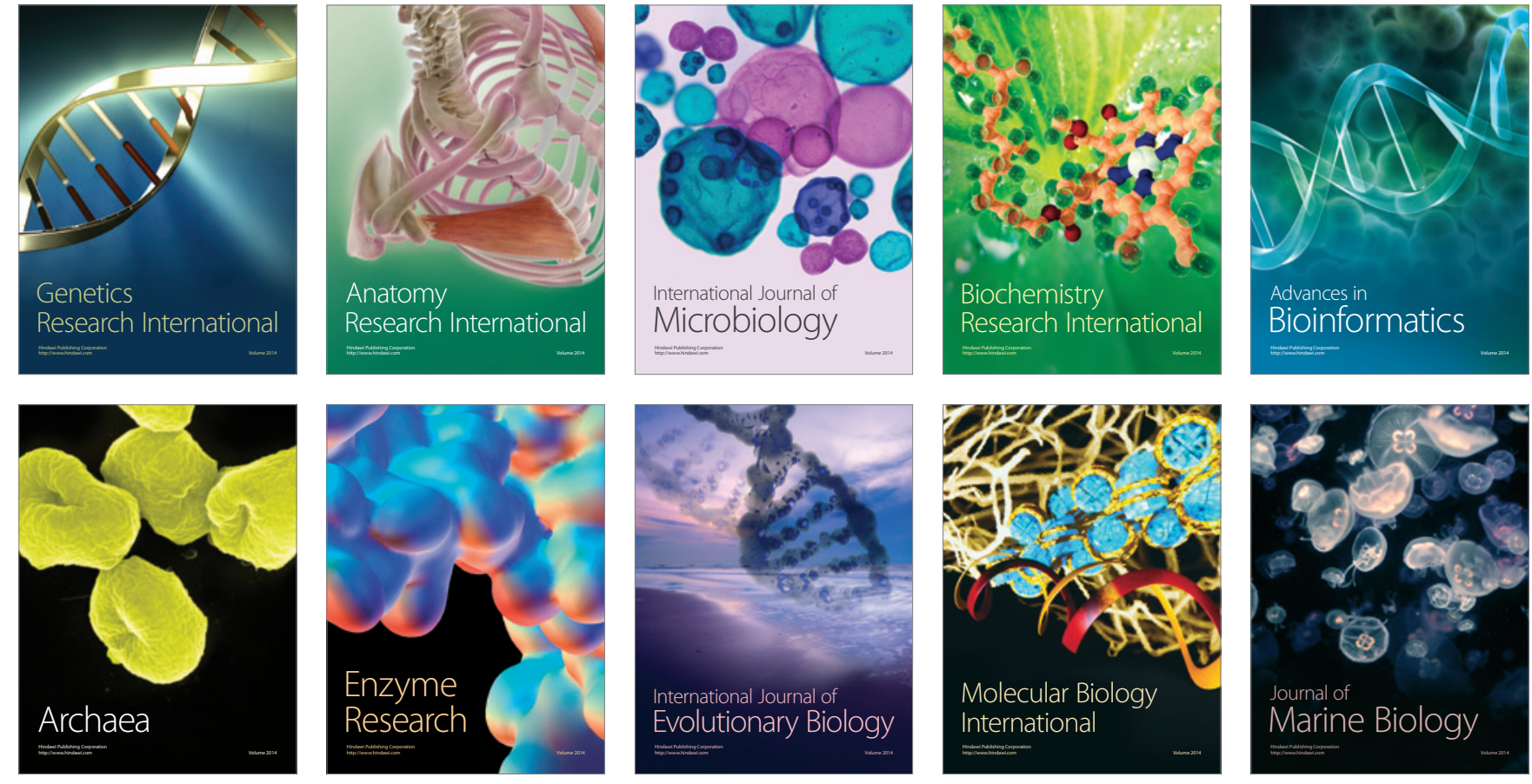